\title{
Attempts to Improve Berry Quality of flame seedless Grapevines
}

\author{
M. A. Hussein and E. H. Abd-Elall \\ Horticulture Department, Faculty of Agriculture, Sohag University, Sohag, Egypt.
}

\begin{abstract}
$\mathbf{T}$
HIS STUDY was carried out during 2014 and 2015 seasons on flame seedless grapevines. The vines were treated with three nitrogen fertilizer concentration (control : $100 \%$ of recommended dose, 50 and $75 \%$ of recommended dose ), combined with foliar application of potassium $2 \mathrm{~cm} / \mathrm{L}$, as well as foliar ethrel at $250 \mathrm{ppm}$ at veraison stage. Removals of basal leaves on the fruiting canes were also done. The purpose of this study was to investigate the effect of these treatments on growth, productivity and berry quality of flame seedless grapevines. Results revealed that, the maximum values of leaf area and shoot length were found on the vines that were treated as the control. Significant high yield and cluster number were found after combined treatment with $\mathrm{N}$ ( $75 \%$ of recommended rate) + foliar Ethrel at $250 \mathrm{ppm}$ and basal leaves remove on the cluster at veraison stage in the first season and $\mathrm{N}(75 \%$ of recommended rate) + foliar potassium at $2 \mathrm{ml} / \mathrm{L}$ at veraison stage in the second season. While, average cluster weight and berry quality were found after combined treatment with Nitrogen at $75 \%+\mathrm{K}$ at $2 \mathrm{~cm} / \mathrm{L}+$ ethrel at $250 \mathrm{ppm}$ along with basal leaves remove application- as compared to all treatment, This was the best treatment in improving color and quality of - flame seedless berries.
\end{abstract}

Keywords: Flame seedless grapevine, Nitrogen, Potassium, Etherl quality, Yield.

\section{Introduction}

Grape is one of the most popular and favorite fruits in Egypt. Grapes rank the second after citrus concerning the acreage and consumption rates. The acreage of cultivated grapevine area in Egypt exhibited a remarkable increase in the last decade reached192934 fed. Which produce 1596169 tons (according to the latest statistics of the ministry of agriculture (2014). The flavor of Flame Seedless fruits is distinctively delicate and sweet, so it is one of the most favorable varieties cultivars in the Egypt. Berry skin colour is an important quality parameter in table grape. Grapes, grown in warm climate regions do not develop a desirable red colour. The colour development in berries is affected by high temperatures above $30{ }^{\circ} \mathrm{C}$ which inhibit anthocyanin production and accumulation. Weak berry color development in red varieties, such as Red Globe, Flame Seedless, and Crimson Seedless, leads to poor quality and, serious economic loss.

Nitrogen $(\mathrm{N})$ is a macro nutrient needed in great amounts to achieve maximum crop yield. $\mathrm{N}$ is an essential constituent of metabolically active compounds such as proteins, enzymes, nucleic acids and chlorophyll. $\mathrm{N}$ plays a major role in cell division and improves photosynthesis process which results in higher accumulation of organic matter in plant tissues. When $\mathrm{N}$ is a limiting factor, the rate and extent of protein synthesis is decreased. As a result, the plant growth is affected. Moreover, the plant becomes stunted and develops leaf chlorosis (Vicente et al., 2014). Inadequate $\mathrm{N}$ supply is often the growth-limiting factor in the field. Consequently, addition of $\mathrm{N}$ usually improves plant growth and yield. The quality of grape berries is strongly influenced by nitrogen availability. Soils with high available nitrogen to plant uptake can increase excessive vegetative growth resulting in poor fruit quality due to the shaded canopies. Increasing the quality of grapes can be achieved by controlling soil nitrogen levels through soil management techniques (Wheeler and Pickering, 2003)

Potassium $(\mathrm{K})$ is an essential nutrient required for plant growth and development and serves an important role in several different plant functions. 
$\mathrm{K}$ is readily translocated throughout the grapevine and may be involved in carbohydrate transport and metabolism. $\mathrm{K}$ cation is used as an osmotic agent in stomata opening and closing. Furthermore, it is an important nutrient in the mechanism of vine water relations. $\mathrm{K}$ neutralizes organic acids and plays a role in controlling fruit's juice acidity and pH (Mullins et al., 1992). During ripening of the grapes, berries become strong sinks for potassium. Excess potassium levels in grape berries may have a negative impact on wine quality, mainly because it decreases free tartaric acid and increases the $\mathrm{pH}$ of grape juice (Mpelasoka et al., 2003).

Ethrel, chloro ethyl phosphonic acid, was developed and named ethephon (De Wilde, 1971). In plants this compound releases ethylene, a natural ripening hormone which is responsible for the physiological action of the ethrel. It has many effects on various crops including promoting flowering, inhibiting vegetative growth, thinning, inducing disease and freezing resistance, improving ripening as well as Inducing better fruit color occurred after Ethrel was applied (De Wilde, 1971, Weaver \& Pool, 1971, Cirami et aI., 1992 and Leilo \& Assis, 1999).

Basal leaf removal treatment of high vegetative vigor grapevines such as Flame Seedless, Ruby Seedless, Crimson Seedless, and Queen, was known to increases light and reduces humidity within the cluster zone. Leaf removals in the cluster zone at veraison stage were used to enhance berry color of red grape varieties such as Flame Seedless and Ruby Seedless. The use of ethephon alone does fulfill requirement of berry coloring and basal leaves still must be removed regardless of the use of Ethrel. Ethrel was reported to increase anthocyanin as compared with the other treatments (El-Sayed, 2013).

The aimed of the present study was to examine the effect of different rates of $\mathrm{N}$ with foliar application of $\mathrm{K}$ and ethrel and basal leaves removal on yield, quality and berries coloring of Flame Seedless grapevines.

\section{Materials and Methods}

This study was carried out during 2014 and 2015 seasons on 45 uniform in vigorous 13- years old Flame Seedless grapevines (not grafted). The vines were grown in sandy soil under drip irrigation system and trained to cane pruning under telephone trellis system. Vines were planted at $2.5 \times 1.75$ meters in the Agri. Experimental Station, Faculty of Agriculture, Sohag University, Sohag, Egypt. .

Treatments and experimental design: The vines were treated with three nitrogen rates (100\% of recommended dose, 50 and $75 \%$ of recommended dose) as ammonium nitrate (NH4 NO3, $33.5 \% \mathrm{~N}$ ), recommended dose $80 \mathrm{~g} \mathrm{~N} /$ vine (recommended by the Ministry of Agriculture), Divided into four times $25 \%$ of N fertilization were added after harvest, $25 \%$ of $\mathrm{N}$ fertilizers were applied before flowering, 50 $\%$ of $\mathrm{N}$ fertilizers were supplied after fruit set to veraison. Combined with application spraying of potassium $(\mathrm{K})$ at $2 \mathrm{ml} / \mathrm{L}$ as $(37.5 \% \mathrm{~K} 2 \mathrm{O}$, Kafr El Zayat Pesticides \& Chemicals Co.) applied at veraison stage, Ethrel (E) at 250 ppm was sprayed at veraison stage and basal leaves removal on the cluster(LR) at veraison stage. The vines were pruned on January1st to six canes per vine, each cane had 8 buds. Six renewal spurs (2 nodes) were maintained per vine. The vines were treated with 3\% hydrogen cyanamide (Dormex) 6 days after pruning. . Regularly the same horticultural practices (fertilization, irrigation etc.,) adopted in Flame seedless orchards of the region. The control vines were fertilized with $80 \mathrm{~g} /$ vine ( $238 \mathrm{~g}$ ammonium nitrate/vine) only.

The treatments are as follows:

- $\mathrm{N}$ recommended rate $80 \mathrm{~g} / \mathrm{vine}$ (control). (238 g ammonium nitrate/vine)

- $\mathrm{N}(50 \%$ of recommended rate $)+$ foliar potassium at $2 \mathrm{ml} / \mathrm{L}$ at veraison stage.

- $\mathrm{N}$ (75\% of recommended rate) + foliar potassium at $2 \mathrm{ml} / \mathrm{L}$ at veraison stage.

- $\mathrm{N}(50 \%$ of recommended rate $)+$ foliar Ethrel at $250 \mathrm{ppm}$ at veraison stage.

- $\mathrm{N}(75 \%$ of recommended rate $)+$ foliar Ethrel at $250 \mathrm{ppm}$ at veraison stage.

- $\mathrm{N}(50 \%$ of recommended rate) + foliar potassium at $2 \mathrm{ml} / \mathrm{L}+$ foliar Ethrel at 250ppm at veraison stage

- $\mathrm{N}(75 \%$ of recommended rate $)+$ foliar potassium at $2 \mathrm{ml} / \mathrm{L}+$ foliar Ethrel at 250 ppm at veraison stage.

- $\quad \mathrm{N}(50 \%$ of recommended rate $)+$ basal leaves removal on the cluster at veraison stage.

- $\mathrm{N}(75 \%$ of recommended rate) + basal leaves removal on the cluster at veraison stage.

Egypt. J. Hort. Vol. 44, No. 2 (2017) 
- $\mathrm{N}(50 \%$ of recommended rate $)+$ foliar potassium at $2 \mathrm{ml} / \mathrm{L}+$ basal leaves removal on the cluster at veraison stage.

- $\mathrm{N}(75 \%$ of recommended rate) + foliar potassium at $2 \mathrm{ml} / \mathrm{L}+$ basal leaves removal on the cluster at veraison stage

- $\mathrm{N}(50 \%$ of recommended rate $)+$ foliar Ethrel at $250 \mathrm{ppm}$ and basal leaves remove on the cluster at veraison stage.

- $\mathrm{N}(75 \%$ of recommended rate $)+$ foliar Ethrel at $250 \mathrm{ppm}$ and basal leaves remove on the cluste at veraison stage.

- $\mathrm{N}(50 \%$ of recommended rat $)+$ foliar potassium at $2 \mathrm{ml} / \mathrm{L}+$ foliar Ethrel at 250 ppm and basal leaves remove on the cluster at veraison stage.

- $\mathrm{N}$ (75\% of recommended rat) + foliar potassium at $2 \mathrm{ml} / \mathrm{L}+$ foliar Ethrel at 250 ppm and basal leaves remove on the cluster at veraison stage.

Experimental Design: The experiment was arranged in randomized complete blocks design, there were 15 treatments, each treatment was replicated three times with five vines as a replicate ( $15 \times 3 \times 3=135$ vines for each season).

The vines of study were subjected to the following estimation.

Vegetative growth:

Leaf area $\left(\mathrm{cm}^{2} /\right.$ leaf $)$ Leaf area $\left(\mathrm{cm}^{2}\right)$ of twenty leaves from those leaves opposite to the basal clusters (last week of May) was measured and calculated (Ahmed and Morsy 1999).

Shoot length: The lengths of 20 shoots were measured in the middle third of the shoot after the growth had ceased.

\section{Yield:}

Average yield per vine $(\mathrm{kg})$ was recorded by counting the clusters on vine and mean weight of cluster, then multiply the number of clusters and mean weight of cluster $(\mathrm{Kg})$. At harvest time representative sample per each replicate was harvested and taken to laboratory to determine the following berry physical properties:

Cluster weight $(g)$ : The clusters were counted per vine and weighed, and then average weight of Cluster/treatment was calculated.

Number of cluster/vine: The clusters were counted per vine and then average number of cluster was recorded.
Average weight of berry ( $g$.)

Chemical Characteristics of Berries:

Total soluble solids in berry juice (TSS) percentage was determined using a hand refractometer and total titratable acidity was measured and expressed as tartaric acid (\%) according to A.O.A.C.(1995).

Total anthocyanin of the berry skin (mg/100 g fresh weight) was determined according to Husia et al. (1965).

Statistical analysis: All the obtained data were tabulated and subjected to the proper statistical analysis using new L.S.D. test at 5\% (according to Mead et al., 1993).

\section{$\underline{\text { Results and Discussion }}$}

Vegetative growth

Shoot length

The data in Table 1 revealed significant differences within all treatment in the two seasons and the shoot length was significantly increased with increasing $\mathrm{N}$ rate. The shoot length ranged from 100 to $135 \mathrm{~cm}$ in the first season, and 85 to $130 \mathrm{~cm}$ in the second season. The greatest shoot length were obtained from the control treatment followed by $\mathrm{N}$ at $75 \%$ of recommended rate + foliar potassium $2 \mathrm{ml} / \mathrm{L}+$ foliar Ethrel 250 ppm and basal leaves removal on the cluster at veraison stage. The least value was obtained from $\mathrm{N}$ at $50 \%$ of recommended rate + basal leaves removal on the cluster at veraison stage treatment in both seasons. The increasing in shoot length may be to increase $\mathrm{N}$ dose, the $\mathrm{N}$ plays a major role in cell division and improves photosynthesis process which results in higher accumulation of organic matter in plant tissues. Consistent to our results, Salem et al. (2004) reported that using with Nitrogen fertilize at $80 \mathrm{~kg} /$ feddan increased shoot length on Thompson Seedless grapevines.

\section{Leaf Area}

The data in Table 1 revealed that there was a significant effect for all treatments on leaf area in both seasons. The leaf area ranged from 101.2 to 128.90 in the first season. The greatest leaf area was obtained from the control treatment while the least value was obtained from $\mathrm{N}$ at $50 \%$ of recommended rate + basal leaves removal in the cluster at veraison stage on the first season and $\mathrm{N}$ at $50 \%$ of recommended rate + foliar potassium $2 \mathrm{ml} / \mathrm{L}$ at veraison stage in the second season. The $\mathrm{N}$ plays a major role in cell division and improves photosynthesis process which results in higher accumulation of organic matter in plant tissues, 
then increased in $\mathrm{n}$ dose lead to improve leaf area. The effect of $\mathrm{N}$ rate on leaf area was reported by Conradie and Saayman, (1989), they found that increasing nitrogen level (160 kg/ha) lead to increase leaf area of White Muscat. In addition, Delgado et al. (2004) stated that the increase in nitrogen fertilization leads to an increase in the leaf area of Thompson Seedless grapes. Moreover, Ruhi et al (1992) mentioned that vines of Merlot grown in the highest $\mathrm{N}$ condition gave a larger leaf area than those grown at low $\mathrm{N}$ condition. In this respect, Abd-El-Razek et al., (2011) found that high $\mathrm{N}$-fertilization increased leaf area of crimson seedless' grape. On the other hand, Hassan (2002) found that K spray increased leaf area of Thompson Seedless grapevines.

\section{Yield components}

Yield: It was clear from the data in Table 1 that there was a significant effect for all treatments on the total yield which ranged from 6.72 to 8.62 $\mathrm{kg} /$ vine in the first season, and from 6.46 to 7.95 $\mathrm{kg}$ in the second one. The highest yield per vine was recorded with the treatment $(\mathrm{N}$ (75\% of recommended rate) + foliar Ethrel at $250 \mathrm{ppm}$ and basal leaves remove on the cluste at veraison stage in first season and $\mathrm{N}$ ( $75 \%$ of recommended rate)
+ foliar potassium at $2 \mathrm{ml} / \mathrm{L}$ at veraison stage. The least value obtained with the vines received $\mathrm{N}$ at $50 \%$ of recommended rate + foliar potassium 2 $\mathrm{ml} / \mathrm{L}+$ foliar Ethrel $250 \mathrm{ppm}$ at veraison stage in the first season and vines treated with $\mathrm{N}$ at $50 \%$ + foliar Ethrel $250 \mathrm{ppm}$ at veraison stage in the second season. The increase in yield obtained by the mentioned substances might be due to that they also increased berry and cluster weight in the present study. Our data are in line with those obtained by Salem, et al. (2004) who reported that there was a positive relationship between the increases in yield and increase the level of nitrogen fertilization. Also, the increase nitrogen level per vine also led to an increase in the yield of Roomy Red grapevine (Ghobrial et al. (1991). A significant increase in 'Roomy Red' yield when the applied nitrogen doses were raised from 20 up to $120 \mathrm{~g} \mathrm{~N} /$ vine was noticed by (Ahmed, et al. 1988). Yield increments of about $10 \%$ in 'Concord' and $29 \%$ in 'Niagara' were recorded for vines fertigated with $80 \mathrm{~kg} \mathrm{~N} / \mathrm{ha}$ (Gay-Eynard 2000). Moreover, Girgis et al. (1998) reported that there was a significant increase in the yield of Thompson seedless vines received high level of $\mathrm{N}$ and $\mathrm{K}$ fertilizer compared with vines received low level.

TABLE 1. Effect of $N$ rates combined with foliar Potassium, foliar Ethrel and basal remove leaf on shoot length $(\mathrm{cm})$, leaf area $(\mathrm{cm} 2)$ and yield $(\mathrm{kg}) /$ vine of flame seedless grapevine.

\begin{tabular}{lcccccc}
\hline \multirow{2}{*}{ Treatments } & \multicolumn{2}{c}{ Shoot length (cm) } & \multicolumn{2}{c}{ Leaf area(cm2) } & \multicolumn{2}{c}{ Yield(kg)/vine } \\
\cline { 2 - 7 } & $\mathbf{2 0 1 4}$ & $\mathbf{2 0 1 5}$ & $\mathbf{2 0 1 4}$ & $\mathbf{2 0 1 5}$ & $\mathbf{2 0 1 4}$ & $\mathbf{2 0 1 5}$ \\
\hline Control & 135.00 & 130.00 & 128.90 & 139.36 & 6.91 & 7.20 \\
N 50\%+ K & 115.00 & 85.00 & 103.70 & 103.30 & 6.98 & 6.87 \\
N 75\% + K & 130.00 & 126.00 & 119.00 & 123.06 & 7.86 & 7.95 \\
N 50\%+ E & 104.33 & 106.66 & 102.13 & 104.86 & 6.74 & 6.46 \\
N 75\%+ E & 120.66 & 119.33 & 121.43 & 126.78 & 7.81 & 7.72 \\
N 50\%+ R. L & 100.00 & 95.00 & 101.20 & 119.20 & 7.1 & 6.74 \\
N 75\%+ R. L & 120.00 & 126.66 & 119.76 & 124.96 & 8.15 & 7.65 \\
N 50\% + K + E & 105.00 & 118.33 & 116.36 & 115.20 & 6.72 & 7.07 \\
N 75\%+ K + E & 125.33 & 126.66 & 124.76 & 124.73 & 7.41 & 7.30 \\
N 50\%+ K + R. L & 115.00 & 115.33 & 116.36 & 122.96 & 7.02 & 7.08 \\
N 75\% + K + R. L & 118.00 & 126.66 & 124.76 & 129.86 & 7.80 & 7.28 \\
N 50\%+ E+ R. L & 116.00 & 117.00 & 116.66 & 124.21 & 7.19 & 7.00 \\
N 75\%+ E + R. L & 117.33 & 123.33 & 125.43 & 127.96 & 8.62 & 7.44 \\
N 50\%+ K + E + R. L & 116.33 & 116.66 & 116.33 & 115.30 & 7.26 & 6.98 \\
N 75\%+ K + E + R. L & 127.66 & 129.33 & 128.60 & 133.33 & 7.81 & 7.74 \\
\hline New L.S.D. at 5\% & 14.49 & 18.05 & 9.96 & 19.30 & 0.828 & 1.04 \\
\hline
\end{tabular}




\section{Number of Clusters/vine}

The data in Table 2 showed that the greatest number of cluster per vine was obtained in vines treated with $\mathrm{N}$ at $75 \%$ of recommended rate + foliar Ethrel $250 \mathrm{ppm}$ and basal leaves removal on the cluster at veraison stage in the first season and vines treated with $\mathrm{N}$ at $50 \%+$ basal leaves removal on the cluster at veraison stage in the second. The least values of number of cluster per vine were obtained with control vines and those treated with the treatment $\mathrm{N} \mathrm{50 \%} \mathrm{recommended}$ rate + foliar potassium $2 \mathrm{ml} / \mathrm{L}+$ foliar Ethrel $250 \mathrm{ppm}$ at veraison stage in first seasons. In the second season the differences between treatments were not big enough to be significant. From these results, the positive effect of $\mathrm{N}$ rate, folair potassium, folair etherl and basal leave removal may be explained by the improving effect of such treatments on nutritional status of the vines specially the relatively higher minerals, carbohydrate, chlorophylls contents in the leaves obtained by these treatments, which certainly reflected on increasing fruit number per vine. These results are in line with those of Gay-Eynard (2000) who found that fertigated nitrogen with 80 $\mathrm{kg} /$ ha was attributable to cluster number increase

\section{Average Cluster Weight}

The data in Table 2 indicated that there was a significant effect by all treatments on average cluster weight in both seasons. The highest average cluster was obtained with vines treatment with $\mathrm{N}$ at $75 \%$ of recommended rate + foliar potassium $2 \mathrm{ml} / \mathrm{L}+$ foliar Ethrel $250 \mathrm{ppm}$ and basal leaves removal on the cluster at veraison stage as average of the two seasons. The least value was observed in vines treated with $\mathrm{N} \mathrm{50 \%}$ recommended rate + foliar Ethrel $250 \mathrm{ppm}$ at veraison stage in both seasons. The data showed that the reduction in $\mathrm{N}$ rate to $50 \%$ and $75 \%$ caused a parallel reduction in cluster weight as compared to control treatment (as average of both seasons). Such result may be caused by number of berries per cluster, weight of berries, $\mathrm{N}$ rate, potassium, Ethrel and basal leaves removal improve nutritional status of the vines specially the relatively higher minerals, carbohydrate, chlorophylls contents in the leaves obtained by these treatments, which certainly reflected on increasing fruit weight per vine. Abd El-Razek et al. (2011) reported that increasing N concentrations was found to improve vegetative growth (leaf area, cane diameter), cluster weight and berry weight of crimson seedless grape.

TABLE 2. Effect of $N$ rates combined with foliar Potassium, foliar ethrel and basal remove leaf on number of cluster/vine, Cluster weight (g) and Berry weight (g) of flame seedless grapevine.

\begin{tabular}{lcccccc}
\hline \multirow{2}{*}{ Treatments } & \multicolumn{2}{c}{ Number of cluster/vine } & \multicolumn{2}{c}{ Cluster weight (g) } & \multicolumn{2}{c}{ Berry weight (g) } \\
\cline { 2 - 6 } & $\mathbf{2 0 1 4}$ & $\mathbf{2 0 1 4}$ & $\mathbf{2 0 1 4}$ & $\mathbf{2 0 1 5}$ & $\mathbf{2 0 1 4}$ & $\mathbf{2 0 1 5}$ \\
\hline Control & 29.00 & 29.33 & 238.3 & 245.3 & 2.53 & 2.50 \\
N 50\%+ K & 31.66 & 31.66 & 220.7 & 217.3 & 2.13 & 2.33 \\
N 75\%+ K & 31.66 & 31.66 & 248.3 & 251.3 & 2.63 & 2.53 \\
N 50\%+ E & 31.33 & 30.66 & 215.3 & 211.0 & 2.16 & 2.20 \\
N 75\%+ E & 32.33 & 30.66 & 241.7 & 252.0 & 2.60 & 2.60 \\
N 50\%+ R. L & 33.00 & 31.00 & 217.3 & 217.6 & 2.43 & 2.30 \\
N 75\%+ R. L & 33.33 & 30.33 & 244.7 & 252.3 & 2.76 & 2.66 \\
N 50\%+ K+ E & 29.00 & 30.33 & 232.0 & 233.3 & 2.46 & 2.56 \\
N 75\% + K + E & 30.00 & 30.00 & 247.0 & 243.6 & 2.80 & 2.86 \\
N 50\% + K + R. L & 30.00 & 30.33 & 234.0 & 233.6 & 2.46 & 2.50 \\
N 75\%+ K+ R. L & 31.33 & 29.33 & 249.0 & 248.3 & 2.83 & 2.83 \\
N 50\%+ E+ R. L & 30.33 & 30.33 & 237.3 & 231.0 & 2.50 & 2.46 \\
N 75\%+ E + R. L & 35.00 & 30.00 & 246.3 & 248.0 & 2.80 & 2.76 \\
N 50\%+ K + E + R. L & 30.66 & 29.33 & 237.0 & 238.0 & 2.63 & 2.50 \\
N 75\%+ K + E + R. L & 30.66 & 30.33 & 255.0 & 255.3 & 2.96 & 2.93 \\
\hline
\end{tabular}


Physical and chemical characteristics of berry Berry weight

The data in Table 2 revealed that the effect of $\mathrm{N}$ rate combined along with foliar application of $\mathrm{K}$ and $\mathrm{E}$ and removed leaves had a significant effect on average berry weight. The highest berry weight was recorded with the treatment $(\mathrm{N}$ at $75 \%$ of recommended rate + foliar potassium 2 $\mathrm{ml} / \mathrm{L}+$ foliar Ethrel ( $250 \mathrm{ppm}$ ) and basal leaves removal from the cluster at veraison stage) in both seasons. The least obtained the vines treated with $\mathrm{N} 50 \%$ recommended rate + foliar Ethrel 250 ppm at veraison stage in both seasons. Such result may be caused by potassium foliar application at veraison be involved in sugar transport to berries This increases the Berry weight. Results presented here are in line with those of Mohsen, (2011) and Thakur et al., (2008), who showed that foliar application of $\mathrm{K}$ increased the berry weight of Crimson Seedless. Moreover, Abd ElRazek et al. (2011) reported that Increasing $\mathrm{N}$ concentrations leads to improved berry weight of Crimson Seedles . In addition, Caspari et al. (1998) reported that removing of leaves increased berry weight of 'Sauvignon blanc' grapes. Also, Okamoto et al. (2003) and Gay-Eynard (2000) found that fertigated nitrogen with $80 \mathrm{~kg}$ /ha was attributable to increase berry weight. While, Main and Morris (2004) observed that leaf removal treatments had no effect on berry weight of 'Cynthiana' grapes.

\section{Total soluble solids (TSS)}

According $t$ the data in Table 3, TSS ranged from 16.7 to 18.5 in the first season and ranged from 16.1 to 18.7 in the second one. The data also revealed that the highest TSS was obtained in vines treated with $(\mathrm{N}$ ( $75 \%$ of recommended rat) + foliar potassium at $2 \mathrm{ml} / \mathrm{L}+$ foliar Ethrel at $250 \mathrm{ppm}$ and basal leaves remove on the cluster at veraison stage) and ( $\mathrm{N}(50 \%$ of recommended rat) + foliar potassium at $2 \mathrm{ml} / \mathrm{L}+$ foliar Ethrel at $250 \mathrm{ppm}$ and basal leaves remove on the cluster at veraison stage) in both seasons. The least value comes from (control) in both seasons. The effect of $\mathrm{N}$ rate combined with foliar application of $\mathrm{K}$ and $\mathrm{E}$, and removed leaves on TSS was significant. The increasing in total TSS caused by potassium foliar application at veraison $\mathrm{k}$ improves sugar transport into berries. In this respect, Abd ElRazek et al. (2011) mentioned that High K fertilization increased T.S.S. of crimson seedless' grape. Bledsoe et al. (1988) studied leaf removal of mature 'Sauvignon blanc' vines and found that the total soluble solids were significantly higher in fruit from vines with leaves removed.

Acidity

The data in Table 3 revealed that the least values of Acidity in juice were obtained on vines treated with $\mathrm{N} 75 \%$ recommended rate + foliar potassium $2 \mathrm{ml} / \mathrm{L}+$ foliar Ethrel250 ppm and basal leaves remove on the cluster at veraison stage followed by N $50 \%$ recommended rate + foliar potassium $2 \mathrm{ml} / \mathrm{L}+$ foliar Ethrel 250 ppm and basal leaves removal on the cluster at veraison stage. The highest value was obtained in control vines in both seasons. The effect of $\mathrm{N}$ rate combined with foliar application of $\mathrm{K}$ and $\mathrm{E}$, and removed leaves had a significant effect on acidity of juice. The decreasing in acidity of juice caused by potassium foliar application at veraison $\mathrm{k}$ improves sugar transport into berries. In this respect Results presented here are in partial agreement with (Mpelasoka et al. 2003) who reported that potassium supplies decreased total acidity on berry of Tempranillo cultivar. Also, Abd El-Razek et al. (2011) mentioned that high K fertilization decreased acidity on Crimson seedless grape. Meanwhile, Bovha (1997) stated that high NK application increased acidity of LastkiRizling grapes. On the other hand, leaf removal of mature 'Sauvignon blanc' vines was found to reduce the titratable acidity (Bledsoe et al. 1988).

\section{Anthocyanin}

Data of both seasons showed that a significant increase in anthocyanin by all treatments as compare with the control treatment (Table 3). Anthocyanin ranged from 27.0 to62.6 mg/100 g in the first season and 28.6 to $62.3 \mathrm{mg} / 100 \mathrm{~g}$ in the second season. The highest values of anthocyanin were obtained from the treatment $\mathrm{N}$ at $75 \%$ of recommended rate + foliar potassium $2 \mathrm{ml} / \mathrm{L}+$ foliar Ethrel $250 \mathrm{ppm}$ and basal leaves remove on the cluster at veraison stage followed by $\mathrm{N} 50$ $\%$ recommended rate + foliar potassium $2 \mathrm{ml} / \mathrm{L}+$ foliar Ethrel $250 \mathrm{ppm}$ and basal leaves removal on the cluster at veraison stage. The lowest value comes from the control treatment. The improving in anthocyanin may be caused by decrease $\mathrm{N}$ dos, foliar potassium, foliar ethereal an basal leave removal. Results presented here agreed with those of Weaver \& Pool (1971), Cirami et al. (1992), Leilo \& Assis (1999), De Wilde (1971) and Sommers, (1977) they found that suitable potassium nutrition was able to increase both coloring and polyphenolic content of berries. 
Similarly, Topalovié et al. (2011) reported that an increase in total anthocyanins after foliar applications of $\mathrm{P}$ and $\mathrm{K}$ was noticed. Also, Abd El-Razek et al. (2011) stated that High $\mathrm{K}$ and low $\mathrm{N}$ level fertilization increased anthocyanin on crimson seedless' grape. Ethylene plays a role in grapevine berry ripening and an increase in ethylene content just before veraison and encourages some of the related processes such as anthocyanin accumulation Dal Ri et al. (2010).

\section{Conclusion}

From the data in this study the treatment $75 \%$ of recommended $\mathrm{N}$ rate + foliar potassium $2 \mathrm{ml} / \mathrm{L}$ + foliar Ethrel250 ppm and basal leaves remove on the cluster at veraison stage followed by $\mathrm{N} 50$ $\%$ recommended rate + foliar potassium $2 \mathrm{ml} / \mathrm{L}+$ foliar Ethrel $250 \mathrm{ppm}$ and basal leaves removal on the cluster at veraison stage gave the best results on yield and fruit quality of flame seedless grapevine.

Acknowledgements: The authors are thankful to Sohag University, Horticulture Department for financing the project to conduct the present study. Funding statements: The authors received no external funding for this study Conflicts of interest: no conflicts of interest to declare

TABLE 3. Effect of $\mathbf{N}$ rates combined with foliar Potassium, foliar Ethrel and basal remove leaf on TSS (\%), acidity (\%) and anthocyanin Mg/100g of flame seedless grapevine.

\begin{tabular}{lcccccc}
\hline \multirow{2}{*}{ Treatments } & \multicolumn{2}{c}{ TSS (\%) } & \multicolumn{2}{c}{ Acidity (\%) } & \multicolumn{2}{c}{ Anthocyanin } \\
\cline { 2 - 7 } & $\mathbf{2 0 1 4}$ & $\mathbf{2 0 1 4}$ & $\mathbf{2 0 1 4}$ & $\mathbf{2 0 1 5}$ & $\mathbf{2 0 1 4}$ & $\mathbf{2 0 1 5}$ \\
\hline Control & 16.7 & 16.1 & 0.691 & 0.626 & 27.0 & 28.6 \\
N 50\%+ K & 17.6 & 17.0 & 0.687 & 0.587 & 34.6 & 35.0 \\
N 75\% + K & 17.5 & 16.9 & 0.669 & 0.584 & 37.6 & 36.6 \\
N 50\% + E & 18.1 & 17.3 & 0.666 & 0.562 & 51.0 & 57.0 \\
N 75\% + E & 18.4 & 18.3 & 0.655 & 0.566 & 53.3 & 53.6 \\
N 50\%+ R. L & 18.3 & 18.1 & 0.659 & 0.549 & 39.0 & 38.6 \\
N 75\% + R. L & 18.3 & 18.4 & 0.669 & 0.559 & 42.0 & 39.6 \\
N 50\% + K + E & 18.3 & 18.0 & 0.661 & 0.566 & 53.6 & 52.3 \\
N 75\% + K + E & 18.2 & 17.6 & 0.648 & 0.557 & 52.3 & 54.0 \\
N 50\% + K + R. L & 18.1 & 17.5 & 0.656 & 0.558 & 42.6 & 41.3 \\
N 75\% + K + R. L & 18.4 & 17.7 & 0.651 & 0.568 & 41.3 & 40.6 \\
N 50\%+ E+ R. L & 18.3 & 17.9 & 0.648 & 0.552 & 55.0 & 53.3 \\
N 75\%+ E + R. L & 18.5 & 18.0 & 0.648 & 0.584 & 54.3 & 55.0 \\
N 50\%+ K + E + R. L & 18.5 & 18.6 & 0.645 & 0.548 & 60.0 & 60.0 \\
N 75\%+ K + E + R. L & 18.5 & 18.7 & 0.644 & 0.545 & 62.6 & 62.3 \\
\hline New L.S.D. at 5\% & 0.437 & 0.535 & 0.014 & 0.028 & 3.90 & 4.12 \\
\hline
\end{tabular}




\section{Reference}

Abd El-Razek, E., Treutter, D., Saleh, M.M.S., ElShammaa, M., Amera, A. Fouad and Abdel Hamid, N. (2011) Effect of nitrogen and potassium fertilization on productivity and fruit quality of 'crimson seedless' grape, Agriculture and Biology journal of North America ISSN Print: 2151-7517, ISSN Online: 2151-7525.

Ahmed, F.F., Elsayed, M.A. and Maatouk M.A. (1988) response of Red Roomy grapevines to nitrogen application. II. Yield and berries quality. Annals Agric. Sci. Ain Shams Univ., 33, 451- 469.

Ahmed, F.F. and Morsy M.H. (1999) A new method for measuring leaf area in different fruit species. Minia J. Agric. Res. Develop., 19 (1), 96- 105.

Association of Official Agricultural Chemists (1995) Official Methods of Analysis (A.O.A.C), $12^{\text {th }}$ ed., Benjamin Franklin Station, Washington D.C. U.S.A. pp. $490-510$.

Bledsoe, A. M., Kliewer, W. M. and Marois, J. J. (1988). Effects of timing and severity of leaf removal on yield and fruit composition of Sauvignon blanc grapevines. Amer. J. Enol. Vitic., 39, 49-54.

Bovha, D. (1997). Comparison of conventional with reduced fertilizer application in grapevine. SAD, Revija za Sadja stvoVino gradnistvo in Vinarstvo. 8 (9), 17-21. (Hort. Abst., 68: 1082).

Caspari, H.W., Lang, A. and Alspach, P. (1998) Effects of girdling and leaf removal on fruit set and vegetative growth in grape. Amer. J. Enol. Vitic., 49, $359-366$.

Cirami, R.M., Cameron, U. and Hedberg, P.R. (1992) Special cultural methods for table grapes. In: Coombe, B.G. \& Dry, P.R (Ed.). Viticulture, Vol. 2. Winetitles, Adelaide, Australia. pp. 279-301.

Conradie, W.J. and Saayman, D. (1989) Effects of longterm nitrogen, phosphorus, and potassium fertilization on Cheninblanc vines. I. Nutrient demand and vine performance. Am. J. Enol. Vitic., 40, 85-90.

Dal Ri, A., Pilati, S., Velasco, R., Moser, C., Costa, G. and Boschetti, A.( 2010) Ethylene production during grape berry development and expression of genes involved in ethylene biosynthesis and response. Acta Hort. (ISHS) 884:73-80.
De Wilde, R.C. (1971) Practical applications of (2-chloroethyl) phosphonic acid in agricultural production. Hort. Science 6, 12-17.

Delgado, R., Martin, P., Del Alamo, M. and Gonzalez, M. (2004) Changes in phenolic composition of grape berries during ripening in relation to vineyard nitrogen and potassium fertilization rates. J. Sci. Food and Agric., 84, 623-630.

Egyptian Ministry of Agriculture Statistics, (2014) Statistics and Economic Affairs Sector, Ministry of Agric. and Land Reclamation, Egypt.

El-Sayed M.E.A. (2013) Improving Fruit Quality and Marketing of "Crimson Seedless" Grape Using Some Preharvest Treatments. Journal of Horticultural Science \& Ornamental Plants 5 (3): 218-226, 2013 ISSN 2079-2158.

Gay-Eynard, G. (2000) Nitrogen effects on yield and canopy of White Muscat grapevines. XXV International Horticultural Congress, Part 2: Mineral Nutrition and Grape and Wine Quality. Acta Hort., 512, 47-54.

Ghobrial, G.H.F., Hassan, F.F and Rizk, I.A. (1991) Yield and leaf mineral constituents in relation to season frequency of nitrogen applied to Thompson seedless vineyard. J. Agri. Sci. Mansura Univ., 16, 1854- 1858.

Girgis, V.H., Eshennawy, S.I. and El-Mogy, M.M. (1998) Studies on the optimum grape cv. 'Cardinal'. J. Agric. Food Chem., 59, $10303-10310$.

Hassan, A. S. A. (2002) Effect of some GA3, yeast, nitrogen and potassium foliar spray treatments on yield, fruit quality and leaf characteristics of Thompson seedless grapevines. Zagazig J. Agric. Res., 29 (1),73-97.

Husia, C.L., Luh, B.S. and Chichester, C.D. (1965) Anthocyanin in free stone peach. J. Food Science, 30, 5-12.

Leao, P.C. and Assis, J.S. (1999). Effects of ethephon on colour and quality of Red Globe grape in the Sao Francisco Valley. Revista Brasileira de Fruticultura, 21, 84-87.

Main, G.L. and Morris, J.R. (2004) Leaf-removal effects on Cynthiana yield, juice composition, and wine composition. Amer. J. Enol. Vitic., 55, 147-152. 
Mead, R., Currnow, R.N. and Harted, A.M. (1993) Statistical Methods in Agricultural and Experimental Biology. $2^{\text {nd }}$ ed. Chapman \& Hall London, pp. 10-44.

Mohsen, A.T., (2011) Attempts to improve the berry quality and storability of grape «Crimson Seedless» with potassium compounds under desert conditions. Hort. Sci. \& Ornamen. Plants, 3, 75-85.

Mpelasoka, B.S., Schachtman, D.P., Treeby, M.T. and Thomas, M. (2003) A review of potassium nutrition in grapevines with special emphasis on berry accumulation. Aust. J. Grape and Wine Res., 9,154-168.

Mullins, M.G., Bouquet, A. and Williams, L.E. (1992) Biology of the Grapevine. Cambridge University Press, New York.

Okamoto, G., Onishi, H. and Hirano, K. (2003) Effect of fertilizer application levels on anthocyanoplast development in Pione grape skin under a root-zone restricted condition. Am. Soc. Enol. Vitic., 54, PthP Annual Meeting, Reno, Nevada.

Ruhi, E.H., Fuda, A.P. and Treeby, M.T. (1992) Effect of potassium, magnesium and nitrogen supply on grape juice composition of Riesling, Chardonnay and Caberent Souvignon vines. Australian J. EXP. Agric., 32, 645-649.

Salem, A.T., Kilany, A.E. and Shaker, G.S. (2004) The influence of NPK, phosphorus source and potassium foliar application on growth and fruit quality of Thompson Seedless grapevines. XXVI International horticultural, Toronto, Canada. Acta Hort., 640, 163-173.
Sommers, T.C. (1977) A connection between potassium levels in the harvest and relative quality in Australian red wine, Australian Wine, Brewing and Spirit Rev, 24, 32-34.

Thakur, S. A. f., Arora, N.K., Sidhu, A.S. and Brar, J.S., (2008) Effect of potassium sprays on the quality of Perlette grapes. Acta Hort., 785, 201-206.

Topalovió, A., Slatnar, A., Tampar, F., Kneevió, M. and Veberi, R. (2011) Influence of foliar fertilization with $\mathrm{P}$ and $\mathrm{K}$ on chemical constituents of grape $\mathrm{cv}$. 'Cardinal'. J. Agric. Food Chem., 59, 103 03-103 10.

Vicente T.O., Oscar, G.V.T., Martha, L.D.P., Héctor, S.N., Antonio, R.M., Rosa, M.M.A., Luis, A.V.A. and Irán, A.T. (2014) Role of Nitrogen and Nutrients in Crop Nutrition. Journal of Agricultural Science and Technology, B4 (2014) 29-37.

Weaver, R.J. and Pool, R.M. (1971) Effect of (2-chloroethyl) phosphonic acid (ethephon) on maturation of Vitis vinifera L. J. Amer. Soc. Hort. Sci., 96, 725-727.

Wheeler S.J. and Pickering, G.J. (2003) Optimizing grape quality through soil management practices. Food, Agriculture \& Environment, 1 (2), 190-197.

(Received 02/11/2017; accepted 14/12/2017) 


\section{محاولات لتحسين جودة الحبات فى كرمات العنب الفليم \\ محمد احمد حسين و عماد الدين حافظ عبدالعال

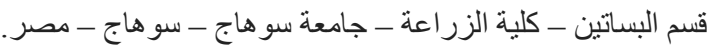

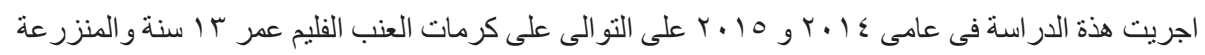

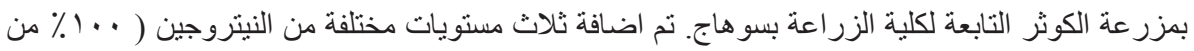

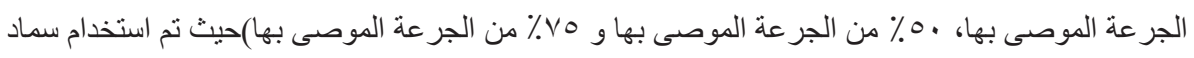

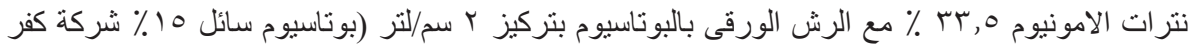

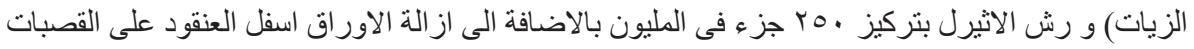

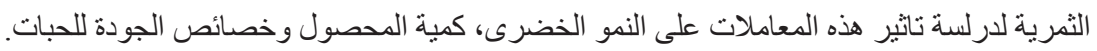

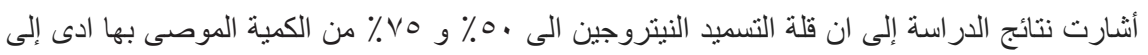

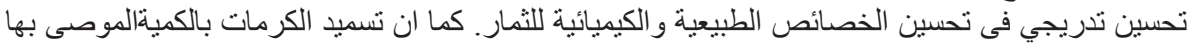
( · ( ( ) ادى الى زيادة طول الافرع و مساحة الورقة وذلك مقارنة بباقى المعاملات.

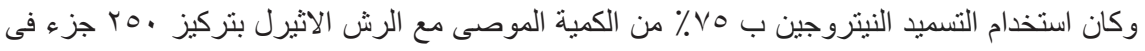

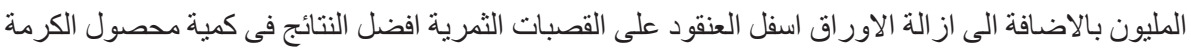

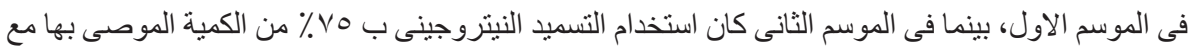

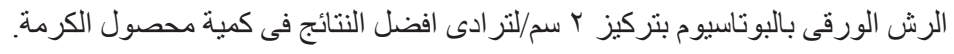

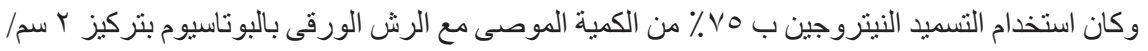

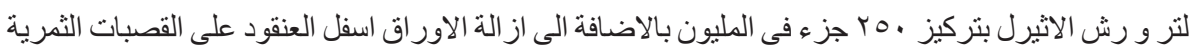

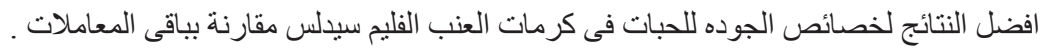

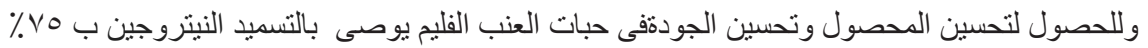

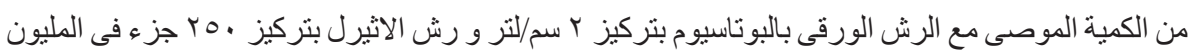

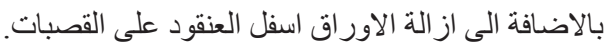

